\title{
MORTALITY FROM PRIMARY TUMOURS OF BONE IN ENGLAND AND WALES, 1961-63
}

\author{
BY \\ J. T. BOYD, M.B., D.P.H., AND R. DOLL, M.D., D.Sc., F.R.C.P., F.R.S. \\ Medical Research Council's Statistical Research Unit, University College Hospital Medical School \\ G. B. HILL, M.B., M.Sc. \\ General Register Office \\ AND \\ H. A. SISSONS, M.B., F.C.Path. \\ Institute of Orthopaedics, Postgraduate Medical Federation, University of London
}

Assessment of the relationship between bone cancers and suspected aetiological factors has been hindered by the lack of accurate measures of the incidence of the disease. With the development of cancer registration schemes, an increasing amount of incidence data is becoming available (Price, 1958; Doll, Payne, and Waterhouse, 1966), but we still lack data for the United Kingdom as a whole, or for any one area over a sufficiently long period to provide useful evidence of trends in incidence with time. Until recently, most estimates of incidence came indirectly from mortality data which, in the absence of any dramatic changes in the efficacy of treatment, might reasonably be expected to indicate changes with time or differences in incidence between different areas. Previous examinations of mortality attributed to primary malignant bone tumour in England and Wales (Mackenzie, Court Brown, Doll, and Sissons, 1961), in Canada (Phillips, 1965), and in the United States (Auerbach, 1964) have, however, demonstrated the inadequacy of bone tumour rates based on certified causes of death. In the study of mortality in England and Wales, special enquiry as to the nature of the diagnoses attributed to bone tumours in the years 1951-53 indicated that at ages under 65 years almost half the deaths (45 per cent.) were due to causes other than primary bone tumour. Exclusion of these deaths from other causes allowed a more reliable estimate of the mortality from primary bone tumours and of the geographical variation in this mortality in different parts of England and Wales (Court Brown, Doll, Heasman, and Sissons, 1961). The study also provided more reliable data for comparisons between various types of tumour in men and in women at different ages.
The 1951-53 study established standards for a period immediately preceding the explosion of the first megaton fusion device in November, 1952. It was intended to provide base-line data agalnst which future trends in mortality might be assessed. In the present study a similar analysis of mortality attributed to primary malignant bone tumours in England and Wales in 1961-63 has been undertaken:

(a) to examine trends in mortality over the decade,

(b) to ascertain whether these more recent data confirmed the overall pattern emerging from the earlier study. Examination of trends in mortality has been amplified by a limited extension of data to include deaths, in solocted age groups, occurring during the next three years (1964-66).

\section{METHOD}

Except for two minor amendments, the current investigation has followed the mothods dascribed for the previous study (Mackenzie and others, 1961). The General Register Office extracted records of all deaths attributed to malignant tumours of the bone (No. 196 in the International Statistical Classification of Disease, World Health Organisation, 1949) which occurred in England and Wales in the three years 1961-63 among persons aged under 75 years (under 65 years in the 1951-53 study) and in the three years 1964-66 among persons under 45 years of age. From the death entry, information was obtained about the sex and age of the patient, place of death, usual residence, and occupation. The certified cause of death was also copied in full. If the case had been registered in the national cancer registration scheme and details of the basis of the diagnosis were available, the details were extracted 
from the records. If not, and the patient had died in hospital, the hospital was written to and enquiries were made about:

(1) the final hospital diagnosis;

(2) whether the diagnosis had been made at autopsy or operation, or, if not, the nature of the evidence on which the diagnosis had been based;

(3) if a histological examination had been made, the histological type of tumour;

(4) if the patient was over 25 years of age, whether there was any evidence of Paget's disease of bone (a new question not asked in the previous enquiry).

If there was no evidence that the patient had attended hospital the doctor who signed the death certificate was asked whether the diagnosis had been made after investigation in a hospital. If so, he was asked the name of the hospital and the approximate date of attendance. If not, he was asked to give the evidence on which the diagnosis was based.

From these enquiries, additional information was obtained for all bone tumour deaths registered during 1961-63. Cases were reviewed individually by us and were classified in three groups according to the certainty and nature of the diagnosis:

(1) Satisfactory evidence of a primary bone tumour.

(2) Satisfactory evidence that the condition was not due to a primary bone tumour.

(3) Evidence of presence or absence of a primary bone tumour uncertain.

Cases with histological evidence of the type of tumour were classified in seven groups-osteosarcoma, chondrosarcoma, fibrosarcoma, Ewing's tumour, chordoma, giant-cell tumour, and other tumours including undifferentiated and unspecified sarcoma.

It should be noted that the current investigation, and its predecessor, were both orientated specifically towards an assessment of errors in the certification, and subsequent coding, of deaths registered as due to bone cancer, i.e. assigned to I.C.D. rubric 196. On general grounds it is, perhaps, reasonable to accept this type of error as the major one affecting accuracy of national data on bone tumour mortality. There remain, however, two others less amenable to assessment on a national basis and not investigated in the present study: (i) Deaths among patients with confirmed bone cancers classified, either correctly or incorrectly, as due to some other cause. The present investigation based on deaths registered as bone tumours, had no means of detecting deaths in this category. Some relevant data were, however, supplied by the cancer registry of the South West Regional Hospital Board (Vick, personal communication) and provided details of 45 cases of bone tumours (at ages 0 to 64 years) notified to the registry during the years 1954-56, and followed up for 5 years, or to death if this occurred earlier. Scrutiny of death certificate details relating to the 37 who died left little doubt that all except two deaths would have been correctly assigned to bone tumour. The two exceptions related to a female aged 12 years notified to the registry as a bone sarcoma in 1956 and dying in the same year with a death certificate diagnosis of "sarcoma thigh", and a male aged 31 years registered as an osteogenic sarcoma in 1954 whose death in 1959 was certified as due to "sarcoma right foot". While it is the normal practice of the General Register Office to make further enquiries about such cases before classifying the tumour to bone, other tissues, or some more general category, we have no positive evidence that this practice was, in fact, followed for the two death certificates in question. If it was not, or if standard enquiry failed to provide any further information allowing their correct assignment to bone tumour (I.C.D. 196), then both deaths may have been wrongly classified as due to "malignant neoplasms of other and unspecified sites" (I.C.D. 199). Although it is, perhaps, unwise to draw firm conclusions from these limited data, they suggest a possible error of about 5 per cent. due to the assignment of deaths among patients with confirmed bone tumours to other causes.

(ii) Changes in bone tumour fatality rates which might, for example, follow any advance in treatment methods. Relevant data are lacking and the detection of such changes was clearly beyond the scope of the present investigation. Any material change in fatality would, however, be particularly relevant to mortality comparisons between different periods of time (e.g. between 1951-53 and 1961-63).

\section{RESULTS}

Altogether 1,324 deaths were attributed to primary tumours of the bone in persons under 75 years during the three years 1961-63. Of these, eight were excluded because the death related to a foreign national ( 3 cases) or because the cause of death had 
been wrongly assigned ( 5 cases). Among the remaining 1,316 cases, there were 704 (53 per cent.) in which the correct diagnosis was thought to have been a primary bone tumour. In a further fourteen cases ( 1 per cent.), the possibility that there was a primary bone tumour was regarded as uncertain. In the remainder (46 per cent.), no primary bone tumour was thought to have been present.

The 1951-53 study was confined to deaths under 65 years. Among 1,169 deaths there were $179(15 \cdot 3$ per cent.) for whom no further information could be obtained. Of the remaining 990,516 (52 per cent.) were classified as primary bone tumours, 25 ( 3 per cent.) as "uncertain", and 449 (45 per cent.) as not primary bone tumours. In the present study the number of deaths relating to persons under 65 years of age was 916 . Of this total, 533 (58 per cent.) were classified as primary bone tumours, eleven (1 per cent.) as "uncertain", and 372 (41 per cent.) as not primary bone tumours.

In 1951-53, histological evidence of the nature of the tumour was available in 77 per cent. of the cases in which the diagnosis of a primary bone tumour was accepted. The comparable proportion from 1961-63 data relating to death under 65 years was 86 per cent. Among older patients (65 to 74 years) histological evidence was less frequently available ( 58 per cent. of 171 accepted tumours). The distribution of various histological types is shown in Table I.

\section{ReLIABILITY OF CERTIFICATION}

The 1961-63 data did not confirm the difference between men and women noted in the earlier survey, in that the percentage of cases confirmed as bone
TABLE I

NUMBER OF TUMOURS (1961-63) OF EACH HISTOLOGICAL TYPE ACCEPTED AS PRIMARY TUMOURS OF BONE, BY AGE GROUP

\begin{tabular}{|c|c|c|c|}
\hline \multirow{2}{*}{ Type of Tumour } & \multicolumn{3}{|c|}{ No. of Cases } \\
\hline & $\begin{array}{c}0-64 \\
\text { yrs }\end{array}$ & $\begin{array}{c}65-74 \\
\text { yrs }\end{array}$ & $\begin{array}{c}0-74 \\
\text { yrs }\end{array}$ \\
\hline $\begin{array}{l}\text { Osteosarcoma } \\
\text { Chondrosarcoma } \\
\text { Fibrosarcoma } \\
\text { Ewing's tumour } \\
\text { Chordoma } \\
\text { Giant-cell tumour } \\
\text { Others (including undifferentiated and } \\
\text { unspecified sarcomas) }\end{array}$ & $\begin{array}{r}212 \\
59 \\
49 \\
27 \\
21 \\
7 \\
84\end{array}$ & $\begin{array}{r}46 \\
13 \\
12 \\
0 \\
3 \\
3 \\
22\end{array}$ & $\begin{array}{r}258 \\
72 \\
61 \\
27 \\
24 \\
10 \\
106\end{array}$ \\
\hline $\begin{array}{l}\text { Total Histological Evidence } \\
\text { No Histological Evidence }\end{array}$ & $\begin{array}{r}459 \\
74\end{array}$ & $\begin{array}{l}99 \\
72\end{array}$ & $\begin{array}{l}558 \\
146\end{array}$ \\
\hline Total Accepted as Tumours & 533 & 171 & 704 \\
\hline
\end{tabular}

tumours was almost identical in the two sexes (59 and 58 per cent. respectively for deaths at 0 to 64 years). On the other hand, present results (Table II) demonstrated an overall age pattern similar to that of the 1951-53 data. Reliability of certification was low (about 40 per cent.) in the very young ( 0 to 4 years), rose to over 90 per cent. at 15 to 19 years, and declined to about 40 per cent. at 50 to 74 years.

It was again apparent (Table III) that the proportion of confirmed tumours showed wide variations according to whether or not Paget's disease was mentioned on the death certificate, and to the pathological description given by the doctor who signed the certificate. 97 per cent. of cases with specific mention of Paget's disease on the certificate were accepted as primary bone tumours. Among those with no reference to Paget's disease, the percentage confirmed ranged from 86 per cent. among

TABLE II

NUMBER AND PERCENTAGE OF CASES (1961-63) IN WHICH CERTIFIED DIAGNOSIS OF PRIMARY BONE TUMOUR WAS CONFIRMED, BY AGE AND SEX

\begin{tabular}{|c|c|c|c|c|c|c|c|c|c|c|c|c|c|c|c|c|c|c|}
\hline \multirow{2}{*}{ Sex } & \multirow{2}{*}{ Final Diagnosis } & \multicolumn{15}{|c|}{ Age (yrs) } & \multirow{2}{*}{$\begin{array}{l}0-64 \\
\text { yrs }\end{array}$} & \multirow{2}{*}{$\begin{array}{c}\text { All } \\
\text { Ages }\end{array}$} \\
\hline & & 0 & 5- & 10 & 15- & 20 & $25-$ & $30-$ & 35- & $40-$ & 45- & $50-$ & $55-$ & 60 & 65- & 70 & & \\
\hline \multirow[t]{2}{*}{ Male } & $\begin{array}{l}\text { Primary bone tumour } \\
\text { Other diagnosis }\end{array}$ & $\frac{1}{2}$ & 11 & 22 & $\begin{array}{r}67 \\
6\end{array}$ & $\begin{array}{r}30 \\
3\end{array}$ & $\begin{array}{r}13 \\
4\end{array}$ & $\begin{array}{r}16 \\
3\end{array}$ & $\begin{array}{l}15 \\
13\end{array}$ & $\begin{array}{l}18 \\
12\end{array}$ & $\begin{array}{l}24 \\
22\end{array}$ & $\begin{array}{l}30 \\
41\end{array}$ & $\begin{array}{l}38 \\
54\end{array}$ & $\begin{array}{l}42 \\
67\end{array}$ & $\begin{array}{l}44 \\
60\end{array}$ & $\begin{array}{l}41 \\
62\end{array}$ & $\begin{array}{l}327 \\
231\end{array}$ & $\begin{array}{l}412 \\
353\end{array}$ \\
\hline & $\begin{array}{l}\text { Per cent. primary bone } \\
\text { tumour }\end{array}$ & 33 & \multicolumn{2}{|c|}{89} & \multicolumn{2}{|c|}{91} & \multicolumn{2}{|c|}{81} & \multicolumn{2}{|c|}{57} & \multicolumn{2}{|c|}{46} & \multicolumn{2}{|c|}{40} & \multicolumn{2}{|c|}{41} & 59 & 54 \\
\hline \multirow{2}{*}{ Female } & $\begin{array}{l}\text { Primary bone tumour } \\
\text { Other diagnosis }\end{array}$ & $\begin{array}{l}4 \\
6\end{array}$ & $\begin{array}{r}13 \\
4\end{array}$ & $\begin{array}{r}32 \\
6\end{array}$ & $\begin{array}{r}37 \\
2\end{array}$ & $\begin{array}{r}12 \\
6\end{array}$ & $\begin{array}{l}6 \\
2\end{array}$ & $\begin{array}{l}5 \\
5\end{array}$ & $\begin{array}{l}7 \\
4\end{array}$ & $\begin{array}{l}9 \\
8\end{array}$ & $\begin{array}{l}16 \\
10\end{array}$ & $\begin{array}{l}20 \\
26\end{array}$ & $\begin{array}{l}22 \\
27\end{array}$ & $\begin{array}{l}23 \\
46\end{array}$ & $\begin{array}{l}37 \\
60\end{array}$ & $\begin{array}{l}49 \\
47\end{array}$ & $\begin{array}{l}206 \\
152\end{array}$ & $\begin{array}{l}292 \\
259\end{array}$ \\
\hline & $\begin{array}{l}\text { Per cent. primary bone } \\
\text { tumour }\end{array}$ & 40 & \multicolumn{2}{|c|}{82} & \multicolumn{2}{|c|}{86} & \multicolumn{2}{|c|}{61} & \multicolumn{2}{|c|}{57} & \multicolumn{2}{|c|}{50} & \multicolumn{2}{|c|}{38} & \multicolumn{2}{|c|}{45} & 58 & 53 \\
\hline \multirow{3}{*}{$\begin{array}{l}\text { Male } \\
\text { and } \\
\text { Female }\end{array}$} & All diagnoses & 13 & 29 & 63 & 112 & 51 & 25 & 29 & 39 & 47 & 72 & 117 & 141 & 178 & 201 & 199 & 916 & 1,316 \\
\hline & $\begin{array}{l}\text { Per cent. primary bone } \\
\text { tumour }\end{array}$ & 38 & 83 & 86 & 93 & 82 & 76 & 72 & 56 & 57 & 56 & 43 & 42 & 37 & 40 & 45 & 58 & 53 \\
\hline & $\begin{array}{l}\text { Per cent. primary bone } \\
\text { tumour (1951-53) }\end{array}$ & 40 & 68 & 81 & 86 & 81 & 62 & 60 & 49 & 49 & 41 & 43 & 35 & 40 & - & - & 52 & - \\
\hline
\end{tabular}


TABLE III NUMBER AND PERCENTAGE OF CASES (1961-63) AGED 0 TO 64 YEARS IN WHICH CERTIFIED DIAGNOSIS
OF PRIMARY BONE TUMOUR WAS CONFIRMED, BY BONE OF ORIGIN AND PATHOLOGICAL DESCRIPTION OF TUMOUR

\begin{tabular}{|c|c|c|c|c|c|c|c|c|c|c|c|c|c|c|c|}
\hline \multirow{4}{*}{$\begin{array}{l}\text { Certified Bone } \\
\text { of Origin }\end{array}$} & \multirow{2}{*}{\multicolumn{3}{|c|}{$\begin{array}{c}\text { Reference to Paget's } \\
\text { Disease on } \\
\text { Death Certificate }\end{array}$}} & \multicolumn{9}{|c|}{ No Reference to Paget's Disease on Death Certificate } & \multirow{2}{*}{\multicolumn{2}{|c|}{$\begin{array}{l}\text { All Cases } \\
\text { Certified as } \\
\text { Malignant } \\
\text { Bone Tumour }\end{array}$}} & \multirow{4}{*}{$\begin{array}{c}\text { Per } \\
\text { cent. } \\
\text { Pri- } \\
\text { mary } \\
\text { Bone } \\
\text { Tu- } \\
\text { mour } \\
\text { (1951 } \\
-53 \\
\text { Data) }\end{array}$} \\
\hline & & & & \multicolumn{3}{|c|}{$\begin{array}{l}\text { Certified Specific } \\
\text { Histological Type } \\
\text { of Sarcoma }\end{array}$} & \multicolumn{3}{|c|}{$\begin{array}{l}\text { Certified as } \\
\text { Sarcoma } \\
\text { Unspecified }\end{array}$} & \multicolumn{3}{|c|}{$\begin{array}{l}\text { Certified as } \\
\text { Carcinoma and } \\
\text { Cancer }\end{array}$} & & & \\
\hline & \multicolumn{2}{|c|}{$\begin{array}{c}\text { No. with Final } \\
\text { Diagnosis }\end{array}$} & \multirow{2}{*}{$\begin{array}{l}\text { Per } \\
\text { cent. } \\
\text { Pri- } \\
\text { mary } \\
\text { Bone } \\
\text { Tu- } \\
\text { mour }\end{array}$} & \multicolumn{2}{|c|}{$\begin{array}{c}\text { No. with Final } \\
\text { Diagnosis }\end{array}$} & \multirow{2}{*}{$\begin{array}{l}\text { Per } \\
\text { cent. } \\
\text { Pri- } \\
\text { mary } \\
\text { Bone } \\
\text { Tu- } \\
\text { mour }\end{array}$} & \multicolumn{2}{|c|}{$\begin{array}{l}\text { No. with Final } \\
\text { Diagnosis }\end{array}$} & \multirow{2}{*}{$\begin{array}{c}\text { Per } \\
\text { cent. } \\
\text { Pri- } \\
\text { mary } \\
\text { Bone } \\
\text { Tu- } \\
\text { mour }\end{array}$} & \multicolumn{2}{|c|}{$\begin{array}{c}\text { No. with Final } \\
\text { Diagnosis }\end{array}$} & \multirow{2}{*}{$\begin{array}{c}\text { Per } \\
\text { cent. } \\
\text { Pri- } \\
\text { mary } \\
\text { Bone } \\
\text { Tu- } \\
\text { mour }\end{array}$} & \multirow[b]{2}{*}{$\begin{array}{c}\text { All } \\
\text { Diag- } \\
\text { noses }\end{array}$} & \multirow{2}{*}{$\begin{array}{c}\text { Per } \\
\text { cent. } \\
\text { Pri- } \\
\text { mary } \\
\text { Bone } \\
\text { Tu- } \\
\text { mour }\end{array}$} & \\
\hline & $\begin{array}{l}\text { Pri- } \\
\text { mary } \\
\text { Bone } \\
\text { Tu- } \\
\text { mour }\end{array}$ & $\begin{array}{l}\text { Other } \\
\text { Diag- } \\
\text { nosis }\end{array}$ & & $\begin{array}{l}\text { Pri- } \\
\text { mary } \\
\text { Bone } \\
\text { Tu- } \\
\text { mour }\end{array}$ & $\begin{array}{l}\text { Other } \\
\text { Diag- } \\
\text { nosis }\end{array}$ & & $\begin{array}{l}\text { Pri- } \\
\text { mary } \\
\text { Bone } \\
\text { Tu- } \\
\text { mour }\end{array}$ & $\begin{array}{l}\text { Other } \\
\text { Diag- } \\
\text { nosis }\end{array}$ & & $\begin{array}{l}\text { Pri- } \\
\text { mary } \\
\text { Bone } \\
\text { Tu- } \\
\text { mour }\end{array}$ & $\begin{array}{l}\text { Other } \\
\text { Diag- } \\
\text { nosis }\end{array}$ & & & & \\
\hline $\begin{array}{l}\text { Upper Limb } \\
\text { Lower Limb } \\
\text { Jaw } \\
\text { Ethmoid } \\
\text { Rest of Skull }\end{array}$ & $\frac{4}{6}$ & $\bar{z}$ & $\begin{array}{l}100 \\
\frac{100}{100}\end{array}$ & $\begin{array}{r}23 \\
134 \\
9 \\
9\end{array}$ & $\begin{array}{r}21 \\
3 \\
3\end{array}$ & $\begin{array}{l}92 \\
86 \\
75 \\
75\end{array}$ & $\begin{array}{r}16 \\
84 \\
5 \\
1 \\
6\end{array}$ & $\begin{array}{r}11 \\
30 \\
17 \\
3 \\
4\end{array}$ & $\begin{array}{l}59 \\
74 \\
23 \\
25 \\
60\end{array}$ & $\begin{array}{l}2 \\
2 \\
- \\
-\end{array}$ & $\begin{array}{r}1 \\
10 \\
90 \\
38 \\
13\end{array}$ & $\begin{array}{r}67 \\
17 \\
0 \\
0 \\
0\end{array}$ & $\begin{array}{r}59 \\
287 \\
124 \\
42 \\
37\end{array}$ & $\begin{array}{r}76 \\
79 \\
11 \\
2 \\
46\end{array}$ & $\begin{array}{r}69 \\
77 \\
17 \\
0 \\
29\end{array}$ \\
\hline $\begin{array}{l}\text { Unspecified } \\
\text { Sacrum } \\
\text { Shoulder Girdle } \\
\text { Ribs or Sternum } \\
\text { Pelvis } \\
\text { Multiple or Unspecified }\end{array}$ & $\begin{array}{r}3 \\
1 \\
1 \\
13\end{array}$ & $\frac{\bar{z}}{\overline{1}}$ & $\begin{array}{r}100 \\
100 \\
100 \\
83 \\
100\end{array}$ & $\begin{array}{r}19 \\
9 \\
8 \\
12 \\
39 \\
60\end{array}$ & $\begin{array}{r}1 \\
1 \\
3 \\
3 \\
10 \\
6\end{array}$ & $\begin{array}{l}95 \\
90 \\
73 \\
80 \\
80 \\
91\end{array}$ & $\begin{array}{r}5 \\
10 \\
5 \\
12 \\
16 \\
9\end{array}$ & $\begin{array}{r}14 \\
4 \\
11 \\
5 \\
11 \\
6\end{array}$ & $\begin{array}{l}26 \\
71 \\
31 \\
71 \\
59 \\
60\end{array}$ & $\frac{1}{1}$ & $\begin{array}{r}36 \\
5 \\
2 \\
1 \\
8 \\
9\end{array}$ & $\begin{array}{r}3 \\
17 \\
0 \\
0 \\
11 \\
0\end{array}$ & $\begin{array}{r}79 \\
31 \\
29 \\
34 \\
91 \\
103\end{array}$ & $\begin{array}{l}35 \\
68 \\
45 \\
74 \\
67 \\
80\end{array}$ & $\begin{array}{l}18 \\
59 \\
53 \\
56 \\
63 \\
80\end{array}$ \\
\hline All Bones & 35 & 1 & 97 & 322 & 53 & 86 & 169 & 116 & 59 & 7 & 213 & 3 & 916 & 58 & \\
\hline $\begin{array}{l}\text { All Bones (1951-53 } \\
\text { data) }\end{array}$ & & & 98 & & & 86 & & & 60 & & & 4 & & 52 & \\
\hline
\end{tabular}

cases certified as specific histological types of sarcoma to 59 per cent. among unspecified sarcoma and 3 per cent. among patients whose growth was described as a carcinoma or "cancer". These proportions were almost identical with comparable 1951-53 figures.

Differences between certified bones of origin were similar to those in the earlier study, though for some sites, notably the spine and ribs, a decrease in numbers certified as cancer of carcinoma contributed to an increase in the overall percentage of accepted tumours. A trend towards more precise certification was also evident in the increasing proportion of tumours certified as specific histological types (from 24 per cent. in 1951-53 to 41 per cent. in 1961-63 of all certified bone tumour deaths).

Data relating to deaths at 65 to 74 years, analysed according to anatomical site and pathological description, are shown in Table IV. The pattern of variation in accuracy of certification was essentially similar to that at younger ages. This older group was, however, weighted with a larger proportion (40 per cent. compared with 24 per cent.) certified as cancer or carcinoma.

\section{MORTALITY RATES}

Age and sex-specific mortality rates based on the 704 deaths accepted as due to primary bone tumours are presented in Table V. Male and female rates displayed similar age patterns; a sharp rise to a peak at 15 to 19 years followed by a rapid decline in immediately succeeding age groups and a more gradual increase thereafter. The level of mortality in adolescence was exceeded only among persons aged 65 years and over.

Crude mortality rates (0 to 64 years) for 1961-63 were lower than those estimated from the 1951-53 data (adjusted to take account of the cases for which no information could be obtained other than what was on the death certificate, Mackenzie and others, 1961). The male rate ( 0 to 64 years) was 53.2 per $10,000,000$ per year compared with 62.9 per $10,000,000$ per year in 1951-53. Female mortality ( 0 to 64 years) also fell over the 10 years, from 38.9 to 33.4 per $10,000,000$. The fall in female death rates was most marked at ages 20 to 44 years. Among women in this age group the average drop in mortality from bone tumours was more than three times that at all ages (48 as against 14 per cent.) and was emphasized by the lack of any comparable change in male rates at this age. The data on male mortality at ages 20 to 44 years suggested that the effect of a moderate fall in the number of registered deaths, and of an increase in population, had been balanced by a higher proportion of cases accepted as primary bone tumours. Rates, therefore, remained reasonably stable. Among females of this age, however, the number of registered bone tumour 
TABLB IV

NUMBER AND PERCENTAGE OF CASES (1961-63) AGED 65 TO 74 YBARS IN WHICH CERTIFIED DIAGNOSIS OF PRIMARY BONE TUMOUR WAS CONFIRMED, BY BONE OF ORIGIN AND PATHOLOGICAL DESCRITION OF TUMOUR'

\begin{tabular}{|c|c|c|c|c|c|c|c|c|c|c|c|c|c|c|}
\hline \multirow{4}{*}{ Certified Bone of Origin } & \multirow{2}{*}{\multicolumn{3}{|c|}{$\begin{array}{c}\text { Reference to Paget's } \\
\text { Disease on } \\
\text { Death Certificate }\end{array}$}} & \multicolumn{9}{|c|}{ No Reference to Paget's Disease on Death Certificate } & \multirow{2}{*}{\multicolumn{2}{|c|}{$\begin{array}{l}\text { All Cases } \\
\text { Certified as } \\
\text { Malignant } \\
\text { Bone Tumou }\end{array}$}} \\
\hline & & & & \multicolumn{3}{|c|}{$\begin{array}{l}\text { Certified Specific } \\
\text { Histological Type } \\
\text { of Sarcoma }\end{array}$} & \multicolumn{3}{|c|}{$\begin{array}{l}\text { Certified as } \\
\text { Sarcoma } \\
\text { Unspecified }\end{array}$} & \multicolumn{3}{|c|}{$\begin{array}{l}\text { Certified as } \\
\text { Carcinoma and } \\
\text { Cancer }\end{array}$} & & \\
\hline & \multicolumn{2}{|c|}{$\begin{array}{c}\text { No. with Final } \\
\text { Diagnosis }\end{array}$} & \multirow{2}{*}{$\begin{array}{c}\text { Per } \\
\text { cent. } \\
\text { Pri- } \\
\text { mary } \\
\text { Bone } \\
\text { Tu- } \\
\text { mour }\end{array}$} & \multicolumn{2}{|c|}{$\begin{array}{l}\text { No. with Final } \\
\text { Diagnosis }\end{array}$} & \multirow{2}{*}{$\begin{array}{l}\text { Per } \\
\text { cent. } \\
\text { Pri- } \\
\text { mary } \\
\text { Bono } \\
\text { Tr- } \\
\text { mour }\end{array}$} & \multicolumn{2}{|c|}{$\begin{array}{c}\text { No. with Final } \\
\text { Diagnosis }\end{array}$} & \multirow{2}{*}{$\begin{array}{c}\text { Per } \\
\text { cent. } \\
\text { Pri- } \\
\text { mary } \\
\text { Bone } \\
\text { Tu- } \\
\text { mour }\end{array}$} & \multicolumn{2}{|c|}{ 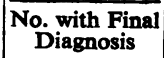 } & \multirow{2}{*}{$\begin{array}{c}\text { Per } \\
\text { cent. } \\
\text { Pri- } \\
\text { mary } \\
\text { Bone } \\
\text { Tu- } \\
\text { mour }\end{array}$} & \multirow[b]{2}{*}{$\begin{array}{c}\text { All } \\
\text { Diag- } \\
\text { noses }\end{array}$} & \multirow{2}{*}{$\begin{array}{c}\text { Per } \\
\text { cent. } \\
\text { Pri- } \\
\text { mary } \\
\text { Bone } \\
\text { Tu- } \\
\text { mour }\end{array}$} \\
\hline & $\begin{array}{c}\text { Pri- } \\
\text { mary } \\
\text { Bone } \\
\text { Tu- } \\
\text { mour }\end{array}$ & $\begin{array}{l}\text { Other } \\
\text { Diag- } \\
\text { nosis }\end{array}$ & & $\begin{array}{c}\text { Pri- } \\
\text { mary } \\
\text { Bone } \\
\text { Tu- } \\
\text { mour }\end{array}$ & $\begin{array}{l}\text { Other } \\
\text { Diag- } \\
\text { nosis }\end{array}$ & & $\begin{array}{c}\text { Pri- } \\
\text { mary } \\
\text { Bone } \\
\text { Tu- } \\
\text { mour }\end{array}$ & $\begin{array}{l}\text { Other } \\
\text { Diag- } \\
\text { nosis }\end{array}$ & & $\begin{array}{c}\text { Pri- } \\
\text { mary } \\
\text { Bone } \\
\text { Tu- } \\
\text { mour }\end{array}$ & $\begin{array}{l}\text { Other } \\
\text { Dias- } \\
\text { nosis }\end{array}$ & & & \\
\hline $\begin{array}{l}\text { Upper Limb } \\
\text { Lower Limb } \\
\text { Jaw } \\
\text { Ethmoid } \\
\text { Rest of Skull } \\
\text { Vertebrae or Spine Unspecified } \\
\text { Sacrum } \\
\text { Shoulder Girdle } \\
\text { Ribe or Sternum } \\
\text { Pelvis } \\
\text { Multiple or Unspecified }\end{array}$ & $\begin{array}{r}4 \\
14 \\
\frac{1}{4} \\
\frac{4}{1} \\
\frac{1}{15} \\
13\end{array}$ & $\begin{array}{l}\overline{2} \\
\bar{z} \\
\bar{z} \\
\bar{z}\end{array}$ & $\begin{array}{r}100 \\
88 \\
100 \\
100 \\
\overline{-} \\
100 \\
\frac{100}{100} \\
\end{array}$ & $\begin{array}{r}3 \\
18 \\
1 \\
1 \\
3 \\
4 \\
5 \\
7 \\
14 \\
5 \\
\end{array}$ & $\begin{array}{l}1 \\
= \\
= \\
= \\
\frac{7}{2} \\
2\end{array}$ & $\begin{array}{r}75 \\
72 \\
100 \\
100 \\
100 \\
100 \\
100 \\
78 \\
88 \\
63 \\
\end{array}$ & $\begin{array}{r}7 \\
24 \\
2 \\
- \\
4 \\
2 \\
2 \\
2 \\
10 \\
3\end{array}$ & $\begin{array}{r}5 \\
13 \\
8 \\
1 \\
3 \\
6 \\
4 \\
3 \\
10 \\
1\end{array}$ & $\begin{array}{r}58 \\
65 \\
20 \\
0 \\
0 \\
40 \\
100 \\
33 \\
40 \\
50 \\
75 \\
\end{array}$ & $\begin{array}{l}= \\
= \\
= \\
\frac{1}{1}\end{array}$ & $\begin{array}{r}72 \\
86 \\
20 \\
9 \\
25 \\
1 \\
1 \\
4 \\
6 \\
4\end{array}$ & $\begin{array}{r}\overline{0} \\
0 \\
0 \\
0 \\
0 \\
0 \\
0 \\
20 \\
0 \\
20\end{array}$ & $\begin{array}{r}20 \\
80 \\
98 \\
21 \\
17 \\
38 \\
7 \\
13 \\
19 \\
57 \\
30\end{array}$ & $\begin{array}{r}70 \\
70 \\
4 \\
0 \\
29 \\
18 \\
86 \\
62 \\
53 \\
68 \\
73\end{array}$ \\
\hline All Bones & 52 & 2 & 96 & 61 & 15 & 80 & 56 & 54 & 51 & 2 & 158 & 1 & 400 & 43 \\
\hline
\end{tabular}

TABLE V

MORTALITY FROM PRIMARY TUMOURS OF THE BONE IN ENGLAND AND WALES, 1961-63, BY SEX, AGES 0 TO 74 YEARS

\begin{tabular}{|c|c|c|c|c|c|c|c|c|c|c|c|c|c|c|c|c|c|c|}
\hline \multirow{2}{*}{ Sex } & \multirow{2}{*}{$\begin{array}{c}\text { Site of } \\
\text { Primary Tumour }\end{array}$} & \multicolumn{17}{|c|}{ Annual Death Rate per $10,000,000$ Persons (age in yrs) } \\
\hline & & 0 & $5-$ & 10 & $15-$ & $20-$ & $25-$ & $30-$ & $35-$ & 40 & $45-$ & 50 & $55-$ & $60-$ & $65-$ & $\overline{70-74}$ & $\overline{0-64}$ & $0-74=$ \\
\hline \multirow{5}{*}{ Male } & Limb Bones & $1 \cdot 7$ & $15 \cdot 7$ & $35 \cdot 1$ & $111 \cdot 3$ & $52 \cdot 3$ & $20 \cdot 3$ & $17 \cdot 7$ & $14 \cdot 8$ & $14 \cdot 6$ & $30 \cdot 6$ & $32 \cdot 1$ & $28 \cdot 0$ & $63 \cdot 8$ & $\overline{108 \cdot 7}$ & $93 \cdot 9$ & $\overrightarrow{33 \cdot 2}$ & $37 \cdot 7$ \\
\hline & $\begin{array}{l}\text { than in Limbs } \\
\text { Bone }\end{array}$ & - & $5 \cdot 9$ & $5 \cdot 5$ & $15 \cdot 1$ & $13 \cdot 6$ & $9 \cdot 0$ & $17 \cdot 7$ & $16 \cdot 9$ & 20.9 & $19 \cdot 7$ & $32 \cdot 1$ & $56 \cdot 0$ & $55 \cdot 1$ & $68 \cdot 5$ & $127 \cdot 0$ & $19 \cdot 0$ & $23 \cdot 9$ \\
\hline & Unspecified & - & - & - & - & $2 \cdot 3$ & - & - & - & $2 \cdot 1$ & $2 \cdot 2$ & 一 & $4 \cdot 7$ & $2 \cdot 9$ & 一 & $5 \cdot 5$ & $1 \cdot 0$ & $1 \cdot 1$ \\
\hline & All Bones & $1 \cdot 7$ & $21 \cdot 6$ & $40 \cdot 6$ & 126.4 & $68 \cdot 2$ & $29 \cdot 4$ & $35 \cdot 4$ & $31 \cdot 6$ & $37 \cdot 6$ & $52 \cdot 5$ & $64 \cdot 3$ & $88 \cdot 6$ & $121 \cdot 8$ & $\overline{177 \cdot 2}$ & $\overline{226 \cdot 4}$ & $\overline{53 \cdot 2}$ & $62 \cdot 6$ \\
\hline & $\begin{array}{c}\text { All Bones } \\
(1951-53)\end{array}$ & $9 \cdot 0$ & $14 \cdot 4$ & $63 \cdot 7$ & $137 \cdot 2$ & $73 \cdot 6$ & $47 \cdot 8$ & $28 \cdot 2$ & $26 \cdot 4$ & $41 \cdot 9$ & $50 \cdot 5$ & $97 \cdot 3$ & $134 \cdot 7$ & $195 \cdot 3$ & - & - & $62 \cdot 9$ & - \\
\hline \multirow{5}{*}{ Female } & $\begin{array}{l}\text { Limb Bones } \\
\text { Bones Other }\end{array}$ & $3 \cdot 6$ & $20 \cdot 6$ & $50 \cdot 4$ & $54 \cdot 6$ & $15 \cdot 8$ & $9 \cdot 4$ & $6 \cdot 8$ & $2 \cdot 1$ & 10.4 & $12 \cdot 6$ & $16 \cdot 3$ & $17 \cdot 2$ & $\overrightarrow{14 \cdot 5}$ & $45 \cdot 4$ & $77 \cdot 0$ & $18 \cdot 5$ & $22 \cdot 3$ \\
\hline & than in Limbs & $3 \cdot 6$ & $6 \cdot 2$ & $9 \cdot 7$ & $15 \cdot 6$ & $11 \cdot 3$ & $4 \cdot 7$ & $4 \cdot 5$ & $12 \cdot 7$ & $8 \cdot 3$ & $21 \cdot 0$ & $24 \cdot 4$ & $30 \cdot 1$ & $41 \cdot 2$ & $56 \cdot 7$ & $94 \cdot 5$ & $14 \cdot 6$ & $20 \cdot 1$ \\
\hline & Unspecified & 一 & - & $1 \cdot 9$ & $2 \cdot 0$ & - & - & - & - & - & 一 & 一 & - & 一 & $2 \cdot 8$ & - & $0 \cdot 3$ & 0.4 \\
\hline & All Bones & $7 \cdot 2$ & $26 \cdot 8$ & $62 \cdot 0$ & $72 \cdot 2$ & $27 \cdot 1$ & $14 \cdot 1$ & $11 \cdot 3$ & $14 \cdot 8$ & $18 \cdot 6$ & $33 \cdot 6$ & $40 \cdot 7$ & $47 \cdot 3$ & $55 \cdot 8$ & $104 \cdot 9$ & $\overline{171 \cdot 4}$ & $33 \cdot 4$ & $42 \cdot 9$ \\
\hline & $\begin{array}{l}\text { All Bones } \\
(1951-53)\end{array}$ & $7 \cdot 4$ & $20 \cdot 0$ & $41 \cdot 5$ & $76 \cdot 1$ & $54 \cdot 2$ & $26 \cdot 9$ & $30 \cdot 3$ & $23 \cdot 5$ & $31 \cdot 4$ & $28 \cdot 0$ & $50 \cdot 0$ & $47 \cdot 8$ & 94.6 & & & 38.9 & \\
\hline
\end{tabular}

deaths in 1961-63 (64) was less than 60 per cent. of comparable figures for 1951-53 (110). There was no change in the proportion of those female cases accepted as primary bone tumours while increase in female population had been of the same order as for males of the same age.

At ages 5 to 9 years, both male and female rates were higher in the more recent study. The number of deaths contributing to these rates was, however, small, and interpretation of the increase in the male rate is complicated by a much higher acceptance rate in the later period (eleven out of twelve in 1961-63 compared with five out of twelve in 1951-53). Among females, acceptance rates at 5 to 9 years remained constant, but had increased from 74 to 84 per cent. at ages 10 to 14 years, where the 1961-63 female mortality rate was again higher than the 1951-53 figure.

An extension of the study to bone tumour deaths under 45 years during the next three years (1964-66) allowed some further evaluation of the main features of direct comparison between 1951-53 and 1961-63 
data (Table VI). This additional material did not substantiate any suggestion of increasing mortality during childhood. Apart from the rather doubtful exception of female mortality at ages 10 to 14 years, where acceptance rates for 1964-66 data increased still further to 97 per cent., rates for the three periods displayed no consistent time trend. It was also clear that disparity between falls in mortality among males and females aged 20 to 44 years was less extreme when measured from 1951-53 to 1964 66. Over this period, the respective average declines in mortality were 18 and 30 per cent. respectively. Age-specific female rates for 1964-66 remained well below those for 1951-53, but were all higher than comparable rates for 1961-63, and it seems that the dramatic fall suggested by the latter experience may have been due, at least in part, to chance fluctuations.

\section{Paget's Disease of Bone}

Estimates of the mortality from primary tumours of bone associated with Paget's disease are given in Table VII. Although the present study incorporated a specific enquiry as to the presence of Paget's disease, the proportion of total mortality (0 to 64 years) reported to be associated with the disease was not materially altered, 13-14 per cent. among males and 8-9 per cent. among females in both periods. No cases were reported with Paget's disease among men and women under 40 years. After $\mathbf{5 0}$ years of age the mortality increased rapidly (Fig. 1) and above 60 years it accounted for more than half of the total bone tumour mortality.

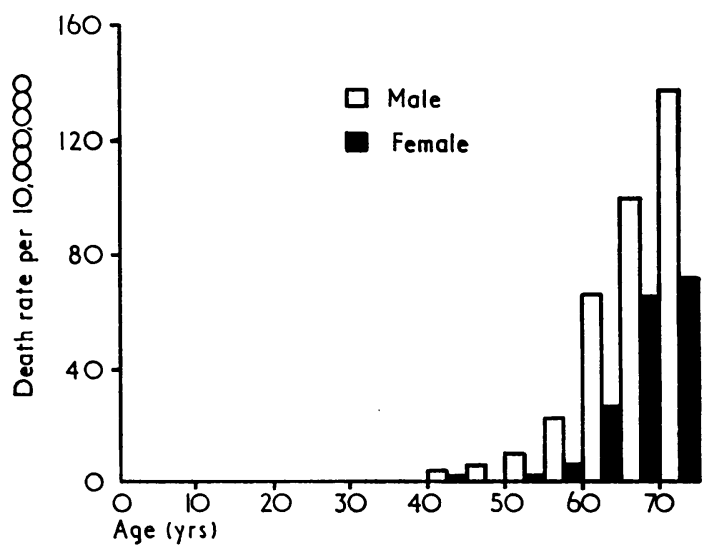

Fig. 1.-Annual death rate per $10,000,000$ persons from primary tumours of bones (all sites) associated with Paget's disease, by sex and 5-year age group up to 74 years, England and Wales, 1961-63

TABLE VI

MORTALITY FROM PRIMARY TUMOURS OF THE BONE AT AGES 0 TO 44 YEARS IN ENGLAND AND WALES, 1951-53, 1961-63, AND 1964-66, BY SEX

\begin{tabular}{|c|c|c|c|c|c|c|c|c|c|c|}
\hline \multirow{2}{*}{ Sex } & \multirow{2}{*}{ Date } & \multicolumn{9}{|c|}{ Annual Death Rate per $10,000,000$ Persons (age in yrs) } \\
\hline & & 0 & $5-$ & $10-$ & $15-$ & $20-$ & 25- & $30-$ & 35- & $40-44$ \\
\hline Male & $\begin{array}{l}1951-53 \\
1961-63 \\
1964-66\end{array}$ & $\begin{array}{l}9 \cdot 0 \\
1 \cdot 7 \\
6 \cdot 3\end{array}$ & $\begin{array}{l}14 \cdot 4 \\
21 \cdot 6 \\
16 \cdot 6\end{array}$ & $\begin{array}{l}63 \cdot 7 \\
40 \cdot 6 \\
45 \cdot 7\end{array}$ & $\begin{array}{l}137 \cdot 2 \\
126 \cdot 4 \\
108 \cdot 9\end{array}$ & $\begin{array}{l}73 \cdot 6 \\
68 \cdot 2 \\
83 \cdot 5\end{array}$ & $\begin{array}{l}47 \cdot 8 \\
29 \cdot 4 \\
39 \cdot 5\end{array}$ & $\begin{array}{l}28 \cdot 2 \\
35 \cdot 4 \\
26 \cdot 6\end{array}$ & $\begin{array}{l}26 \cdot 4 \\
31 \cdot 6 \\
10 \cdot 9\end{array}$ & $\begin{array}{l}41 \cdot 9 \\
37 \cdot 6 \\
34 \cdot 1\end{array}$ \\
\hline Female & $\begin{array}{l}1951-53 \\
1961-63 \\
1964-66\end{array}$ & $\begin{array}{l}7 \cdot 4 \\
7 \cdot 2 \\
8 \cdot 4\end{array}$ & $\begin{array}{l}20 \cdot 0 \\
26 \cdot 8 \\
19 \cdot 4\end{array}$ & $\begin{array}{l}41 \cdot 5 \\
62 \cdot 0 \\
62 \cdot 5\end{array}$ & $\begin{array}{l}76 \cdot 1 \\
72 \cdot 2 \\
76 \cdot 9\end{array}$ & $\begin{array}{l}54 \cdot 2 \\
27 \cdot 1 \\
31 \cdot 5\end{array}$ & $\begin{array}{l}26 \cdot 9 \\
14 \cdot 1 \\
15 \cdot 9\end{array}$ & $\begin{array}{l}30 \cdot 3 \\
11 \cdot 3 \\
23 \cdot 4\end{array}$ & $\begin{array}{l}23 \cdot 5 \\
14 \cdot 8 \\
17 \cdot 9\end{array}$ & $\begin{array}{l}31 \cdot 4 \\
18 \cdot 6 \\
25 \cdot 6\end{array}$ \\
\hline
\end{tabular}

TABLE VII

MORTALITY FROM PRIMARY TUMOURS OF THE BONE ASSOCIATED WITH PAGET'S DISEASE, ENGLAND AND WALES, 1961-63, BY SEX, AGES 40 TO 74 YEARS

\begin{tabular}{|c|c|c|c|c|c|c|c|c|c|c|}
\hline \multirow{2}{*}{ Sex } & \multirow{2}{*}{ Site of Primary Tumour } & \multicolumn{9}{|c|}{ Annual Death Rate per $10,000,000$ Persons (age in yrs) } \\
\hline & & 40- & 45- & $50-$ & 55- & $60-$ & 65- & $70-74$ & $0-64$ & $0-74$ \\
\hline \multirow{3}{*}{ Male } & $\begin{array}{l}\text { Limb Bones } \\
\text { Bones Other than in Limbs } \\
\text { Bone Unspecified }\end{array}$ & $\overline{4 \cdot 2}$ & $\frac{4 \cdot 4}{2 \cdot 2}$ & $\begin{array}{r}6 \cdot 4 \\
4 \cdot 3 \\
-\end{array}$ & $\begin{array}{l}9 \cdot 3 \\
9 \cdot 3 \\
4 \cdot 7\end{array}$ & $\begin{array}{r}34 \cdot 8 \\
29 \cdot 0 \\
2 \cdot 9\end{array}$ & $\begin{array}{r}72 \cdot 2 \\
28 \cdot 2 \\
-\end{array}$ & $\begin{array}{r}66 \cdot 3 \\
66 \cdot 3 \\
5 \cdot 5\end{array}$ & $\begin{array}{l}3.4 \\
2.9 \\
0.7\end{array}$ & $\begin{array}{l}7.8 \\
5.6 \\
0.6\end{array}$ \\
\hline & All Bones & $4 \cdot 2$ & $6 \cdot 6$ & $10 \cdot 7$ & $23 \cdot 3$ & $66 \cdot 7$ & $100 \cdot 4$ & $138 \cdot 1$ & $7 \cdot 0$ & $14 \cdot 1$ \\
\hline & All Bones (1951-53) & $4 \cdot 0$ & $4 \cdot 2$ & $15 \cdot 0$ & $52 \cdot 7$ & $83 \cdot 2$ & - & - & 8.9 & 一 \\
\hline \multirow{3}{*}{ Female } & $\begin{array}{l}\text { Limb Bones } \\
\text { Bones Other than in Limbs } \\
\text { Bone Unspecified }\end{array}$ & $\overline{2 \cdot 1}$ & 二 & $\frac{2 \cdot 0}{-}$ & $\begin{array}{r}2 \cdot 1 \\
4 \cdot 3 \\
-\end{array}$ & $\begin{array}{r}4 \cdot 8 \\
-8\end{array}$ & $\begin{array}{r}19 \cdot 8 \\
22 \cdot 7 \\
2 \cdot 8\end{array}$ & $\begin{array}{r}35 \cdot 0 \\
38 \cdot 5 \\
-\end{array}$ & $\begin{array}{l}0.6 \\
1.9 \\
-\end{array}$ & $\begin{array}{l}3 \cdot 1 \\
4 \cdot 5 \\
0 \cdot 1\end{array}$ \\
\hline & All Bones & $2 \cdot 1$ & - & $2 \cdot 0$ & $6 \cdot 4$ & $26 \cdot 7$ & $45 \cdot 3$ & $73 \cdot 5$ & $2 \cdot 6$ & $7 \cdot 8$ \\
\hline & All Bones (1951-53) & - & 一 & $11 \cdot 8$ & $5 \cdot 3$ & $37 \cdot 3$ & 一 & 一 & $3 \cdot 5$ & - \\
\hline
\end{tabular}




\section{Age Distribution}

Separate examination of mortality from tumours of the limb bones (Table V) demonstrated an age distribution conforming to, but more marked than, the general pattern already noted. Mortality rose sharply to a peak at ages 15 to 19 years and fell away to a minimum at ages 25 to 44 years; it rose again in later life until, at 65 years and over, it exceeded the peak recorded in late adolescence. From the data in Table VII it is apparent that the greater part of the rise in mortality in old age is due to tumours associated with Paget's disease. The variation of mortality with age in the absence of Paget's disease is illustrated in Fig. 2. As in the 1951-53 study, removal of cases associated with Paget's disease produced a marked flattening of the mortality curve at ages over 45 years.

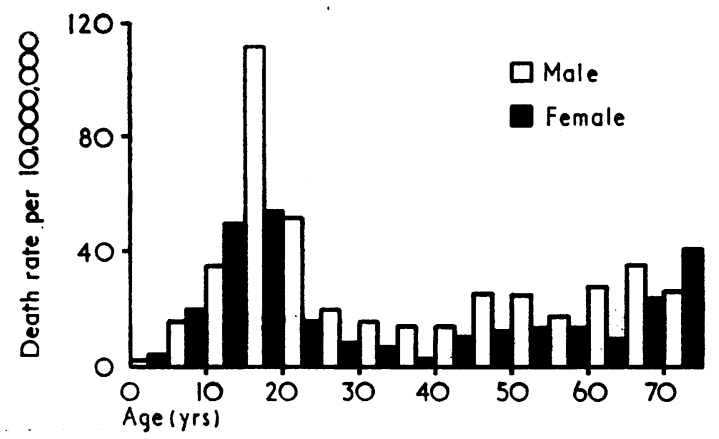

Fio. 2.-Annual death rate per $10,000,000$ persons from primary tumours of limb bones, excluding cases associated with Paget's disease of bone, by sex and 5-year age group up to 74 years, England and Wales 1961-63.

The limited extension of study data to include 1964-66 experience allowed a more detailed scrutiny of age-sex trends of mortality from limb bone tumours through childhood and adolescence (Fig. 3). In both sexes, deaths rose with age to an adolescent peak and then declined sharply. Within this general pattern, however, there was a notable sex difference. A consistent, if small, excess of female mortality was apparent at each age until female mortality reached its peak at 13 years. During the next 3 years, male deaths continued to increase rapidly to a peak at about 16 years when mortality among boys was double that of girls. Although deaths in both sexes then declined at similar rates, mortality among young adults remained predominantly male. The age patterns displayed and the difference between sexes, not evident for deaths assigned to "other bone tumours", were clearly

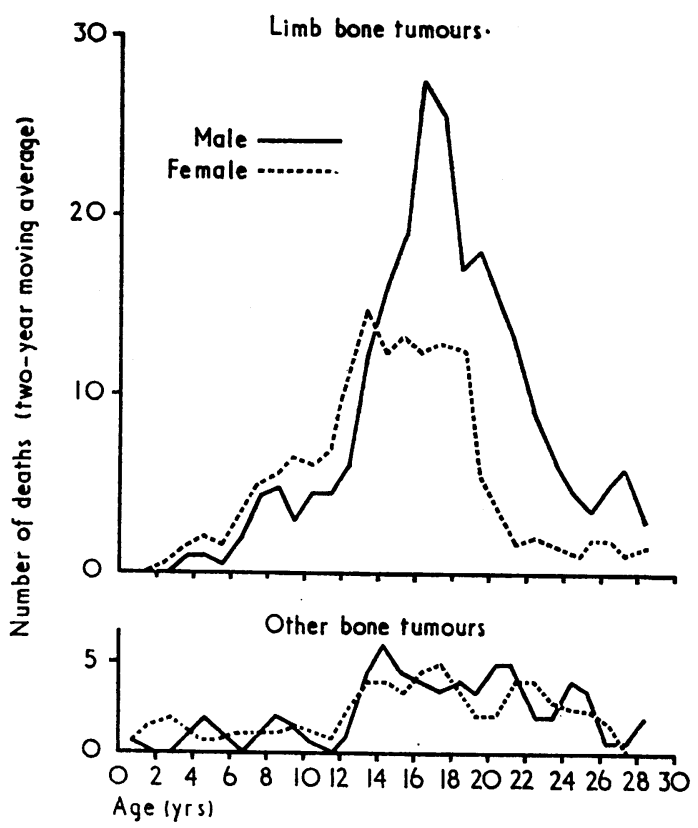

Fig. 3.-Mortality from limb bone tumours and other bone tumours, at age 0 to 29 years, England and Wales, 1961-66, by years of age (2-year moving average) and sex.

consistent with more general trends noted in the less detailed data available for the previous study (Mackenzie and others, 1961). In particular, the close association between peaks in limb bone mortality and adolescent spurts in growth (occurring earlier for girls than boys) has been confirmed. The present data also lend further support to the possibility that the markedly higher rates among adolescent boys may be explained by differences between the sexes in the response of the limb bones to the adolescent growth spurt. At this period the long bones of the limbs increase in length in both sexes; but the increase in length and the relative increase in breadth are substantially greater in boys (Tanner, 1962), and continue to a latter age.

Mortality from primary tumours in bones other than limb bones (Table $V$ ) demonstrated a minor peak at 15 to 24 years before increasing in middle life to reach its highest level at ages 70 to 74 years. The mortality gradient at older ages was again modified, though less so than for tumours of limb bones, by the exclusion of cases associated with Paget's disease (Fig. 4). While an increase with age at 45 years and over remained apparent, the rate of increase was very much less marked and was slower than for most other types of malignant disease. 


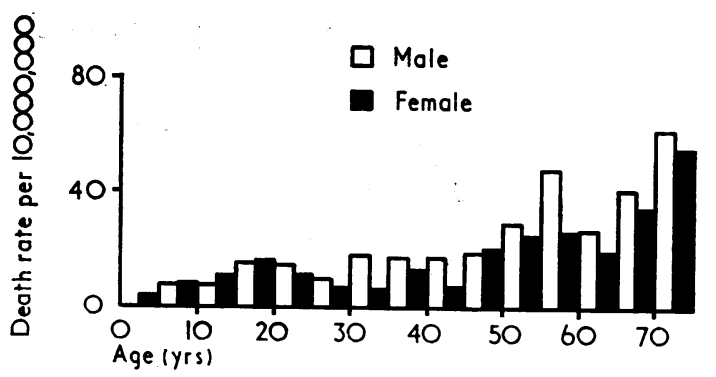

Fig. 4.-Annual death rate per $10,000,000$ persons from primary tumours of bones, other than limb bones, excluding cases associated with Paget's disease of bone, by sex and 5-year age group up to 74 years, England and Wales, 1961-63.

\section{Geographical Distribution of Primary Bone TUMOURS}

Regional variations in bone tumour mortality (1961-63) were examined and compared with similar findings based on 1951-53 data. To facilitate comparison between the two periods, the data have been analysed in the same way as in the earlier study (Court Brown and others, 1961). Thus the current analysis was restricted to deaths at ages 0 to 64 years and observed and expected mortality was compared in the same 39 local authority areas. For each area, the population was known for each sex and 5-year age group at the time of the census of 1961 . Estimates of local populations for both sexes and for all age groups were available also for the three years 1961,1962 , and 1963. The number of bone tumour deaths expected in each area has, therefore, been calculated in three steps. First the census population in each sex and 5-year age group in each area has been multiplied by the ratio between the average population in that group in the whole country throughout the period 1961-63 and the corresponding population recorded at the time of the census. Secondly, the resulting populations in each sex and age group have been multiplied by the corresponding sex and age-specific mortality rates (Table $\mathrm{V}$ ) and the results have been summed for all ages under 65 years. Thirdly, the expected number of bone tumour deaths so obtained has been corrected for differential rates of population increase by multiplying by the ratio between the total population for each area for 1961-63, and the total population obtained for that area by assuming that the rate of population growth in each sex and age group was equal to that for the whole country.

Data were calculated separately for each of the 39 local authority groupings used in the earlier study. These geographical areas had been determined, on the basis of 1951-53 experience, by taking all Counties and County Boroughs of more than
700,000 population with the following exceptions:

(1) If the number of expected deaths (195153) was less than four, the county was combined with a neighbour;

(2) Greater London and the remaining parts of the Home Counties (i.e. Kent, Surrey, Hertfordshire, and Essex) were treated as two areas;

(3) Wales, apart from Glamorganshire and Monmouthshire, was treated as a single unit.

The numbers of deaths observed and expected in each area are shown in Table VIII. The extent of

TABLE VIII

DEATHS FROM PRIMARY TUMOURS OF BONE IN DIFFERENT PARTS OF ENGLAND AND WALES, 1961-63

Observed compared with expected

\begin{tabular}{|c|c|c|c|c|}
\hline \multirow{2}{*}{ Area } & \multicolumn{2}{|c|}{ No. of Deaths } & \multicolumn{2}{|c|}{$\begin{array}{c}\text { Standardized } \\
\text { Mortality } \\
\text { Ratio }\end{array}$} \\
\hline & Observed & Expected & $\begin{array}{c}1961- \\
63\end{array}$ & $\underset{53}{1951-}$ \\
\hline $\begin{array}{l}\text { Northamptonshire, } \\
\text { Peterborough } \\
\text { Liverpool } \\
\text { Cornwall, Isle of Scilly } \\
\text { Sheffield } \\
\text { Monmouthshire } \\
\text { Somerset } \\
\text { Durham } \\
\text { Yorkshire, less Leeds and } \\
\text { Sheffeld } \\
\text { Lancashire, less Liverpool and } \\
\text { Manchester } \\
\text { Wales, less Glamorgan and } \\
\text { Monmouthshire } \\
\text { Manchester } \\
\text { Shropshire, Herefordshire } \\
\text { Norfolk } \\
\text { Suffolk } \\
\text { Nottinghamshire } \\
\text { Staffordshire } \\
\text { Glamorgan } \\
\text { Cumberland, Westmorland } \\
\text { Dovon } \\
\text { Derbyshire } \\
\text { Sussex } \\
\text { Birmingham } \\
\text { Home Counties, less Greater } \\
\text { London } \\
\text { Greater London } \\
\text { Leicestershire, Rutland } \\
\text { Warwickshire, less } \\
\text { Birmingham } \\
\text { Northumberland } \\
\text { Buckinghamshire, } \\
\text { Oxfordshire } \\
\text { Lincolnshire } \\
\text { Cambridgeshire, Huntingdon, } \\
\text { Isle of Ely } \\
\text { Gloucestershire } \\
\text { Berkshire } \\
\text { Bedfordshire } \\
\text { Hampshire, Isle of Wight } \\
\text { Wiltshire } \\
\text { Worcestershire } \\
\text { Cheshire } \\
\text { Leeds } \\
\text { Dorset }\end{array}$ & $\begin{array}{r}13 \\
15 \\
6 \\
9 \\
8 \\
10 \\
23 \\
55 \\
54 \\
13 \\
9 \\
6 \\
7 \\
6 \\
11 \\
21 \\
14 \\
4 \\
9 \\
10 \\
11 \\
12 \\
40 \\
84 \\
7 \\
9 \\
7 \\
\end{array}$ & $\begin{array}{r}5 \cdot 5 \\
8 \cdot 5 \\
3 \cdot 8 \\
5 \cdot 8 \\
5 \cdot 2 \\
6 \cdot 9 \\
17 \cdot 4 \\
43 \cdot 0 \\
42 \cdot 9 \\
11 \cdot 0 \\
7 \cdot 6 \\
5 \cdot 2 \\
6 \cdot 4 \\
5 \cdot 5 \\
10 \cdot 5 \\
20 \cdot 4 \\
14 \cdot 3 \\
4 \cdot 1 \\
9 \cdot 3 \\
10 \cdot 4 \\
11 \cdot 7 \\
13 \cdot 1 \\
43 \cdot 3 \\
94 \cdot 7 \\
8 \cdot 2 \\
10 \cdot 8 \\
9 \cdot 3 \\
9 \cdot 4 \\
8 \cdot 5 \\
4 \cdot 3 \\
11 \cdot 7 \\
5 \cdot 9 \\
4 \cdot 5 \\
16 \cdot 6 \\
5 \cdot 0 \\
6 \cdot 7 \\
15 \cdot 7 \\
5 \cdot 9 \\
3 \cdot 6\end{array}$ & $\begin{array}{l}236 \\
176 \\
158 \\
155 \\
154 \\
145 \\
132 \\
128 \\
126 \\
118 \\
118 \\
115 \\
109 \\
109 \\
105 \\
103 \\
98 \\
98 \\
97 \\
96 \\
94 \\
92 \\
92 \\
92 \\
89 \\
85 \\
83 \\
75 \\
74 \\
71 \\
70 \\
68 \\
68 \\
67 \\
60 \\
60 \\
60 \\
57 \\
51 \\
\end{array}$ & $\begin{array}{r}35 \\
122 \\
103 \\
111 \\
168 \\
68 \\
95 \\
105 \\
101 \\
89 \\
180 \\
115 \\
171 \\
27 \\
81 \\
101 \\
139 \\
84 \\
119 \\
83 \\
137 \\
98 \\
97 \\
74 \\
140 \\
123 \\
141 \\
85 \\
113 \\
129 \\
79 \\
52 \\
69 \\
96 \\
93 \\
50 \\
158 \\
119 \\
93\end{array}$ \\
\hline All Areas & 533 & $532 \cdot 6$ & 100 & 100 \\
\hline
\end{tabular}


the variation is demonstrated by the range of standardised mortality ratios (that is, the ratios of the observed to the expected deaths, expressed as a percentage). In one area (Dorset), with an expectation of 3.6 deaths at national rates, there were no observed deaths from primary bone tumour during the three years. Among remaining areas, standardised mortality ratios varied from 51 in Leeds C.B. to 236 in Northamptonshire (plus Peterborough). In many of the areas, however, the number of recorded deaths was small and the overall variation between areas was, as in 1951-53, within the limits that might be expected due to chance alone $\left(\chi^{2}=\right.$ $49 \cdot 14 ; 38$ d.f.; $0 \cdot 2>P>0 \cdot 1)$. Direct comparison of local standardized mortalities in 1951-53 and 1961-63 revealed no consistent association between them. Some areas, e.g. Cheshire, had high standardized mortality ratios in 1951-53 and low ratios in 1961-63, while in others, e.g. Northamptonshire, the pattern was reversed. Only Monmouthshire had a standardized mortality ratio above 140 in both periods and mortality ratios consistently below 70 were confined to Worcestershire, Bedfordshire, and Berkshire. Calculation of the correlation coefficient based on ranking order of area mortalities in 1951-53 and 1961-63 confirmed the absence of any overall association between local death rates in the two periods $(r=+\cdot 074$; S.E. $0 \cdot 162)$.

While the absence of general association between and within periods cannot be taken as excluding the possibility of local factors, it suggests that effects of any such factors on the incidence of bone tumours are small in comparison with random variation. In the earlier study (Court Brown and others, 1961) it was noted that several counties with low standardized mortalities were grouped together in the southern and south midland regions. The 1961-63 survey provided further data on regional distribution of the disease, and in Fig. 5 the averages of 1951-53 and 1961-63 mortality ratios for each area are presented cartographically. The pattern displayed lends support to earlier impressions in demonstrating a relatively favourable bone mortality in south-eastern England. Among south-eastern counties, Norfolk and Sussex alone experienced a less favourable mortality than the country as a whole, and the area showing a low mortality experience covered sixteen contiguous local authority divisions extending, in the west, to the Severn and, in the north, to the Humber. With the exception of Cumberland and Westmorland, mortality rates were generally higher in the west and north. No clear pattern emerged from the conurbations studied: Liverpool, Manchester, and Sheffield shared a relatively high bone tumour mortality in contrast to Leeds, Birmingham, and

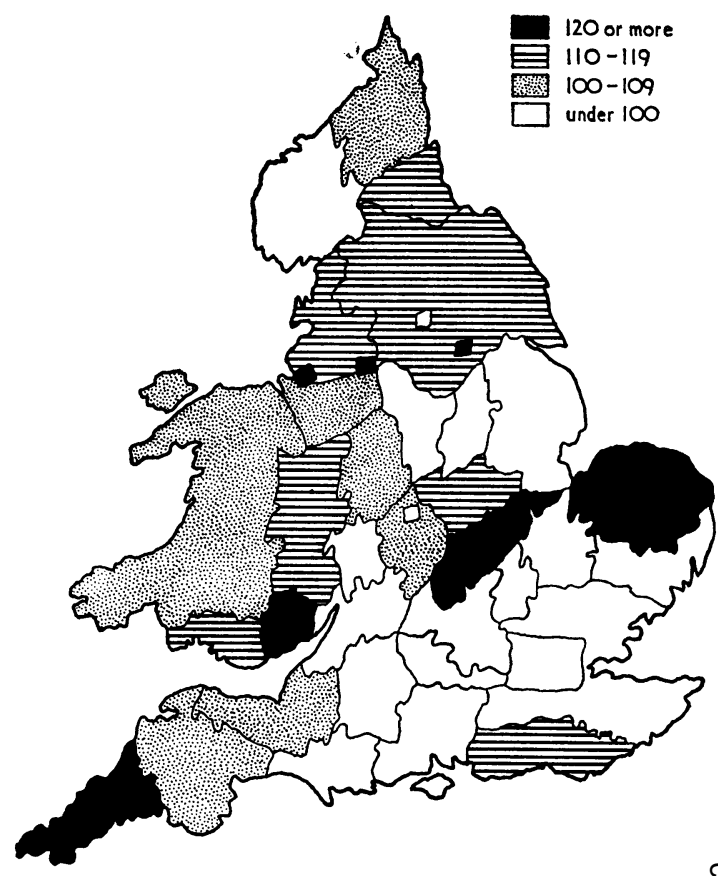

FIG. 5.-Map of England and Wales, showing average standardized mortality ratio for malignant tumours of bone at ages under 65 years in 39 areas.

Greater London where average mortality over the six years was low.

\section{RADIOACTIVITY OF WATER}

In the analysis of 1951-53 bone tumour mortality, availability of data on the radium content of water (Turner, Radley, and Mayneord, 1961) for nineteen areas allowed an examination for possible association between $\alpha$-activity of drinking water and mortality in these areas. Standardized mortality ratios, based on 1961-63 experience, of the nineteen areas have again been compared with the same average measurements of radioactivity (Table IX). The most notable difference from previous findings has been that in 1961-63 the area, Cornwall, with highest measurements of $\alpha$-activity in drinking water had also the highest mortality ratio. With this exception, the present comparison confirms the absence of obvious correlation between the two sets of data and the rank order correlation coefficient $(r=-\cdot 070$; S.E. $0 \cdot 236)$ is not significantly different from zero. Thus neither the current analysis nor the earlier one based on 1951-53 mortality data have provided support for the suggestion of possible association, between radium content of water supplies and local bone tumour mortality, put 
TABLE IX

COMPARISONS BETWEEN STANDARDIZED MORTALITY RATIOS FOR BONE TUMOURS AND LONG-LIVED $\alpha$-ACTIVITY OF LOCAL DRINKING WATER

\begin{tabular}{|c|c|c|c|}
\hline \multirow{2}{*}{ Area } & \multirow{2}{*}{$\begin{array}{c}\text { Standard- } \\
\text { ized } \\
\text { Mortality } \\
\text { Ratios } \\
(1961-63)\end{array}$} & \multicolumn{2}{|c|}{$\begin{array}{c}\alpha \text {-Activity of } \\
\text { Drinking Water } \\
\text { at } 30 \text { Days (1960) }\end{array}$} \\
\hline & & $\begin{array}{l}\text { No. of } \\
\text { Samples }\end{array}$ & $\begin{array}{c}\text { Mean } \\
\text { Value } \\
\text { ( } \mu \mu c . / \text { litre) }\end{array}$ \\
\hline $\begin{array}{l}\text { Dorset } \\
\text { Hampshire, Isle of Wight } \\
\text { Gloucestershire } \\
\text { Lincolnshire } \\
\text { Buckinghamshire, Oxfordshire } \\
\text { Warwickshire, less Birmingham } \\
\text { Greater London } \\
\text { Birmingham } \\
\text { Home Counties, less Greater } \\
\text { London } \\
\text { Sussex } \\
\text { Devon } \\
\text { Glamorgan } \\
\text { Staffordshire } \\
\text { Manchester } \\
\text { Wales, less Glamorgan and } \\
\text { Monmouthshire } \\
\text { Yorkshire, less Leeds and } \\
\text { Sheffield } \\
\text { Somerset } \\
\text { Sheffield } \\
\text { Cornwall, Isle of Scilly }\end{array}$ & $\begin{array}{r}60 \\
68 \\
71 \\
74 \\
83 \\
89 \\
92 \\
92 \\
94 \\
97 \\
98 \\
103 \\
118 \\
118 \\
128 \\
145 \\
155 \\
158\end{array}$ & $\begin{array}{r}1 \\
1 \\
5 \\
1 \\
2 \\
1 \\
6 \\
1 \\
3 \\
1 \\
1 \\
3 \\
2 \\
3 \\
3 \\
7 \\
7 \\
2 \\
1 \\
1 \\
10\end{array}$ & $\begin{array}{l}0 \cdot 11 \\
0 \cdot 23 \\
1 \cdot 20 \\
1 \cdot 34 \\
0 \cdot 17 \\
1 \cdot 60 \\
0 \cdot 54 \\
0 \cdot 07 \\
0 \cdot 38 \\
0 \cdot 11 \\
0 \cdot 34 \\
0 \cdot 36 \\
0 \cdot 91 \\
0 \cdot 07 \\
0 \cdot 07 \\
0 \cdot 41 \\
0 \cdot 33 \\
0 \cdot 09 \\
2 \cdot 23\end{array}$ \\
\hline
\end{tabular}

forward in a recent Illinois-Iowa population study (Petersen, Samuels, Lucas, and Abrahams, 1966).

\section{SUMMARY}

The mortality attributed to primary malignant tumours of bone in England and Wales in 1961-63 has been examined and compared with a similar analysis of 1951-53 experience. Two major aims of the present study have been $(i)$ to examine trends in mortality over the decade, and (ii) to ascertain whether the more recent data confirm the pattern of bone tumour deaths emerging from the earlier study.

Records of deaths of persons under 75 years of age attributed to primary bone tumours were extracted by the General Register Office and for each death a questionnaire was sent to the doctor who signed the death certificate or to the hospital (or its related cancer registry) in which the patient had been treated. Replies received provided evidence about the nature of the diagnosis for all 1,316 cases. In 704 ( 53 per cent.) the diagnosis of a primary bone tumour was confirmed; in 598 (46 per cent.) the diagnosis was thought not to be a primary bone tumour; and in 14 (1 per cent.) the diagnosis was classified uncertain.

Comparison with 1951-53 experience was necessarily restricted to the age-range ( 0 to 64 years) covered by the earlier study. In 1961-63, 553 (58 per cent.) of the 916 deaths relating to persons under
65 years were classified as primary bone tumours compared with 516 (52 per cent.) of 990 deaths in 1951-53. Furthermore, the proportion of confirmed cases with histological evidence of the nature of the tumour was higher in 1961-63 (86 per cent.) than in 1951-53 (77 per cent.).

Earlier indications of factors affecting reliability of certification were confirmed. Reliability was low (about 40 per cent.) in the very young group ( 0 to 4 years), rose to over 90 per cent. at ages 15 to 19 years, and declined to about 40 per cent. at ages 50 to 74 years. 97 per cent. of cases with specific mention of Paget's disease were accepted as primary bone tumours. Among those with no reference to Paget's disease, the percentage confirmed ranged from 86 per cent. among cases certified as specific histological types of sarcoma to 59 per cent. among sarcomas unspecified and 3 per cent. among patients in whom the tumour was described as a carcinoma or "cancer". A trend towards more precise certification was evident in the increasing proportion of tumours certified as specific histological types (from 24 per cent. in 1951-53 to 41 per cent. in 1961-63 of all certified bone tumour deaths).

Crude mortality rates (0 to 64 years) for 1961-63 were lower than those estimated from the 1951-53 data. The male rate was $53 \cdot 2$ (per $10,000,000$ per year) compared with 62.9 in 1951-53, and female mortality fell over the ten years from 38.9 to 33.4 per $10,000,000$ per year. The only notable exception to a general decline in age-specific rates occurred among children aged 5 to 9 years (both sexes) and 10 to 14 years (females). While rates in each of the latter groups were higher in 1961-63, an extension of the study to include their 1964-66 experience did not substantiate any regular trend at these young ages.

Mortality rates in the two sexes displayed similar age patterns; a sharp rise to a peak at 15 to 19 years followed by a rapid decline in immediately succeeding age groups and a more gradual increase thereafter. The level of mortality in adolescence was exceeded only among persons aged 65 years and over. The greater part of the rise in mortality at older ages appeared due to tumours associated with Paget's disease, a feature notably evident among tumours of the limb bones where removal of cases with Paget's disease produced a marked flattening of the mortality curve at ages over 45 years. A breakdown of extended (1961-66) data, by sex and single years of age, confirmed the close time relationship between adolescent peaks in mortality from limb bone tumours and the growth spurt of adolescence.

Regional variations in bone tumour mortality were studied by comparing observed and expected 
mortality from true primary bone tumours in 39 areas of England and Wales over the three years. The patterns displayed lent some support to previous impressions in demonstrating a relatively favourable bone mortality experience in south-east England. Taken as a whole, however, variation throughout the country was no more than could reasonably be attributed to chance and comparison with area mortalities in 1951-53 showed no overall association between local death rates in the two periods.

As in 1951-53, standardized mortality ratios were not significantly correlated with published figures for the long-term radioactivity of drinking water available for nineteen of the areas.

\section{REFERENCES}

AUERBACH, H. (1964). Argonne National Laboratory Reviews, 1, 13 (Human population radiation studies). Court Brown, W. M., Doll, R., Heasman, M. A., and Sissons, H. A. (1961). Brit. J. prev. soc. Med., 15, 167 (Geographical distribution of primary tumours of bone in England and Wales).
Doll, R., Payne, P., and Waterhouse, J. (1966). "Cancer Incidence in Five Continents", International Union against Cancer, Tech. Rep. Springer, Berlin.

Mackenzie, A., Court Brown, W. M., Doll, R., and Sissons, H. A. (1961). Brit. med. J., 1, 1782 (Mortality from primary tumours of bone in England and Wales).

Petersen, N. J., Samuels, L. D., Lucas, H. F., and Abrahams, S. P. (1966). Publ. Hith Rep. (Wash.), 81, 805 (An epidemiologic approach to low-level Radium 226 exposure).

Phillips, A. J. (1965). Canad. med. Ass. J., 92, 391 (A mortality study of primary tumours of bone in Canada).

PRICE, C. H. G. (1958). J. Bone Jt Surg., 40B, 574 (Primary bone-forming tumours and their relationship to skeletal growth).

TANNER, J. M. (1962). "Growth at Adolescence", 2nd ed. Blackwell, Oxford.

TURNer, R. C., RADley, J. M., and MAYNeORD, W. V. (1961). Nature (Lond.), 189, 348 (Naturally occurring alpha-activity of drinking waters).

VICK, R. M. (1962). Personal communication. 